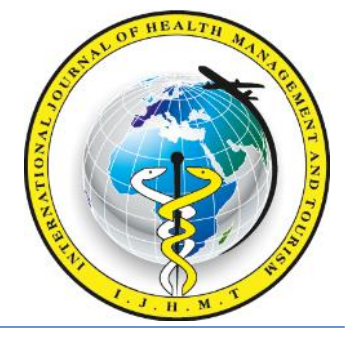

International Journal Of Health Management And Tourism

\title{
A RESEARCH FOR DETERMINING THE OPINIONS ON CITY HOSPITALS EXAMPLE OF ANKARA, THE CAPITAL CITY
}

\section{Merve OZZEYBEK TAS ${ }^{1}$, Dilaver TENGILIMOĞLU² ${ }^{2}$, E. Asuman ATILLA ${ }^{3}$}

\author{
${ }^{1} \mathrm{PhD}$ student in the Ankara Hacı Bayram Veli University, TURKEY \\ E-mail: merveozzeybk@gmail.com, \\ ${ }^{2}$ Professor of Atılım University Department of Business Administration, TURKEY \\ E-mail: dilaver.tengilimoglu@atilim.edu.tr \\ ${ }^{3}$ Associate Professor of Gazi University, Health Services Vocational School, TURKEY \\ E-mail: asumanatilla@gazi.edu.tr,
}

Received: 03.09.2019

Accepted: 16.09.2019

\begin{abstract}
The research has also been carried out in order to research the expectations of individuals and health professionals separately in relation to the service to be provided by city hospitals, examine the differences of knowledge, thought and opinion between these two groups, and analyze in a detailed manner the attitudes of individuals before the city hospital of Ankara province starts to provide services. The research which is conducted by the researchers using the questionnaires developed by obtaining the expert opinion, it was determined that health professionals have more negative opinions compared to citizens regarding city hospitals, in particular the physicians think that the negative effects of the practice of city hospitals are more compared to other health professionals, and health professionals with high level of education agreed with the negative opinions on the practice of city hospitals.
\end{abstract}

Keywords : City Hospital, Public Private Partnership Model, Stakeholders, Health Management, Factor Analysis 


\section{Introduction}

With the neo-liberal state policies being effective after 1980, changes have started to take place in the presentation and financing of public services. This understanding in particular started the seek for the presence of various methods that could be applied while presenting public services and brought together the concept of Public Private Partnership, which came to agenda both in financing and service provision as a fundamental model on which city hospitals rely in our country today (Kerman et al., 2012, pp. 3). Whereas the term Public Private Partnership is defined in various forms in the literature and some interpret this term as a hidden privatization, some see it as the partnership of all interactions between the government and private sector (Raman and Björkman, 2015, pp. 377).

Public Private Partnership Model, which has high diversity in the structuring of risk management, financing and payment mechanisms, has been used by many countries today with various public private mixture combinations (Roehrich, Wright, 2013, pp. 147). For example, UK was the leading of the model as it focused on development/ rehabilitation of the facility and facility management under the name "The Private Finance Initiative -PFI" (https //ppp.worldbank.org/public -privatepartnership/ppp-health). The UK provided the transfer of risk and cost to the contractors, namely the private sector with this model (McKee, Edwards, Atun, 2006, pp. 891). Whereas India adopted a Public Private Partnership Model that is rather directed towards the provision of services, it has benefited from the model not in terms of improvement of the facilities, but also from the point of service provision (https//ppp.worldbank.org/public-private-partnership/ppp-health). In Australia, various Public Private Partnership Models that have different versions have been applied in various states (McKee, Edwards, Atun, 2006, pp. 891).

In its general meaning, this concept which means the coming together of public and private sector, improves the existing health and public health systems and emergence of the institutions (Thadani, 2014, pp. 308). Public Private Partnership (PPP) which is being implemented in particular by developed countries by transferring the management to private sector under state control in the fields where needed in big projects in financial terms, has become a model which is frequently applied in health sector (Çınar et al., 2017, pp. 217). Use of this model in the field of health has been preferred to due to such reasons as facilitating the use of health services under more modern conditions, ensuring that infrastructure projects are completed within a shorter period of time, and provides more budget profitability (Sonğur, Top, 2018, pp. 160). 
There are various Public Private Partnership Models that are being used in different sectors in Turkey. The models generally are Buy-Build-Operate, Build - Own- Operate, Build- OwnOperate-Transfer, Build-Operate-Transfer, Build-Lease- Operate-Transfer, Design-Build-Finance0Operate, Finance, Operating and Maintenance Contract, Design-Operate, and Operating License (Altan et al., 2013, pp. 12). Build-Operate-Transfer model is preferred in Turkey in the field of health services. Build-Operate-Transfer Model "is a special financing model that is developed in order to be used in the realization of projects for which advance technology or high material resources are needed, and it includes payment of the investment cost (including any profit to be acquired), to the capital company or foreign company, by means of purchasing by the administration or service beneficiaries of the goods or services produced by the company during the operation period." (Yerlikaya, 2013, pp. 528).

Start of the implementation of Public Private Partnership Model in the field of health does not have a long history. This model has a history of around 20 years in the field of health. The need to use such a model has emerged basically for two different reasons. One of these two basic needs is the need for private financing support due to restriction of the budget, and the second is the need to benefit from the operating capacities, techniques, skills and knowledge of the private sector (Karasu, 2011, pp. 220). As in the case of the whole world, there is a need to make giant and costly investments in the field of health particularly in Turkey. However, many hospitals and other health facilities that are present in Turkey do not have suitable conditions for providing modern health care services, and this situation means the increase of financial needs. Overcoming the increasing financial needs forced to orient towards alternative method and made it necessary for the health sector to deal with concession practices (Senel Tekin, 2017, pp. 6).

With the 2 additional paragraphs added on 13.08.1999 to Article 47 titled Nationalization and Privatization of the Constitution of the Republic of Turkey which was adopted in 1982, it was stated "The principles and procedures related to privatization of assets and enterprises under the ownership of the state, public economic enterprises and other public legal personalities shall be regulated under laws." and "It shall be regulated under Law which of the investments and services carried out by the state, public economic enterprises and other public legal personalities could be contracted to real or legal persons with private law contracts or could be transferred" (http //www.anayasa.gov.tr/icsayfalar/mevzuat/1982anayasas \%C4\%B1.html). These provisions have functioned as a starting point for starting to use the Public Private Partnership Model, which is being implemented in various sectors today such as the health sector. Following this, Law on Making Certain Investments and Services Within the Framework of Build- Operate - Transfer 
Model was published in 1994 in order to ensure that some investments and services, which are carried out by public institutions and organizations, and which require advanced technology and high material resources, within the framework of Build - Operate- Transfer model (http://www.mevzuat.gov.tr/Mevzuat Metin/1.5.3996.pdf).

In 2006, the Regulation on Constructing the Health Facilities In Exchange of Renting, and Renewal of Services and Areas Other Than Medical Service Areas in Facilities In Exchange of Their Operation was published, and with this regulation, pursuant to additional Article 7 of Basic Law on Health Services No. 3359; it was aimed at determining the principles and procedures wherein; the health facilities, construction of which is decided by Higher Planning Board to be necessary, shall be constructed within the basic standards to be determined and preliminary project to be issued by the Ministry of Health, in exchanging of leasing the same for a maximum period of 49 years and over the price to be determined accordingly to real or private legal persons to be determined with tender, on the real estates owned by the Ministry or the Treasury; for this purpose, these real estates shall be transferred by establishing right of construction, which is independent and with finite term, up to forty nine years, free of charge, in favor of real persons or private law legal persons, on the real estates owned by the Treasury, by the Ministry of Finance; that the lease amounts and the leasing period shall be determined, that the services and areas other than medical services areas in health facilities be renewed in exchange of operation thereof, that the tender method and the qualifications to be asked in bidders be determined, as well as the scope of contracts and other issues (http://www.resmigazete.gov.tr/eskiler/2006/07/20060722-2.htm).

Following the adoption of the Decree Law on Organization and Tasks of the Ministry of Health and Affiliated Institutions No. 663, which has foreseen fundamental changes in the field of health, the Health Investments General Directorate was established in 2013, and the Public - Private Partnership Department was constituted under this unit. With the creation of this unit, the Public Private Partnership Model has acquired a more corporate structure (Sonğur, Top, 2018, pp. 162).

The Ministry of Health is the ministry which uses the Public Private Partnership Model the most. For example, out of 34 Public Private Partnership projects that have been continued in 2016, 17 were carried out by the Ministry of Health, and a high portion of the contracts related to these facilities, and all of the city hospitals projects, were carried out by the Ministry of Health within the framework of Build - Operate - Transfer model (Bülbül, 2017, pp. 103). The Ministry of Health plans to establish 32 city hospitals with 42199 bed capacity in Turkey with the Public Private Partnership Model. Hospitals have put into operation in 5 provinces by August 2018, and it is planned to put into operation more city hospitals by the end of this year. The difference between 
Public Private Partnership Model from other models is that it has more number of stakeholders. Whereas the fact that the shareholders are in good relations with each other positively affects the process, any situation otherwise will prevent the process from progressing in positive direction. For that reason, it is an important issue to determine the expectations of all shareholders from the process. It will be beneficial for the success of the project to carry out works towards the perceptions and attitudes of the health professionals who will work in these hospitals as well as of the citizens from the initial establishment of City Hospitals, and to collect and assess data related to the existing perception

(http://tusside.tubitak.gov.tr/sites/images/sehir_hastaneleri_yonetim_ve_isletim_modeli_whitepaper .pdf). This study, which is designed for this purpose, first gives the method of the research, followed by the findings, and ends with conclusions and recommendations.

\section{Method of the Research}

Many fundamental changes have taken place in Turkish health system with the implementation of Health Transformation Program in Turkey in 2003. Besides many aspects of the program that have been criticized, in order to make an assessment on whether the city hospital practices were successful or unsuccessful, the project shall be handled with all of its aspects and the results of the city hospitals that have been put into practice shall be considered. Considering that there will be a direct impact on the health level of individuals in Turkey with this practice that is a new step in the provision of health services, the purpose of this study is to research the opinions of service providers and service beneficiaries on city hospitals, which are a continuation of Public Private Partnership Model, analyze the differences of knowledge and opinions between the individuals, and analyze in a detailed manner the attitudes and opinions before putting the city hospitals into implementation. Therefore the main problem sentence of the research comprises "there is a difference in the opinions of individuals and health professionals living in Ankara Province related to city hospitals"

The universe of the research comprises the individuals who reside in Ankara Province and who are not health professionals, and the health professionals residing in Ankara Province. The sampling method was used in the research due to time and cost factor. The sample of the research comprises 446 health professionals and 440 non-health professional individuals, who are selected by simple random sampling method. Taking into account the sample sizes accepted for certain universes, it was considered that 384 people would be sufficient for representing the universe up to a population of 100 million at a confidence level of 95\% (Sahin, Gürbüz, 2017). 
The data is collected by means of survey method, which is one of the first degree data collection methods. Two separate questionnaire forms were created in accordance with the purpose of the study, and the expert opinions were used in creating the questionnaire questions. The questionnaire forms were transmitted to health professionals and non-health professional citizens who reside in Ankara province through internet media.

The questions in the questionnaire form used in the study comprise two sections. The first section includes expressions towards identifying the opinions related to city hospitals, and the second section included questions related to the personal information of the participants. In the expressions related to opinions on city hospitals, 5 Likert scale has been used, and was arranged in the form of 1: Totally Agree; 2: Agree; 3:No Idea At All; 4:Disagree; 5:Totally Agree. Since the questions were asked negative, at the analysis stage the scale was corrected as 1: Totally Disagree; 5:Totally Agree.

Prior to factor analysis applied, KMO and Bartlett test results were analyzed. According to this, in order to apply explanatory factor analysis to the structure comprising 23 items, it was considered that 440 samples would be sufficient $(\mathrm{KMO}=0,900)$. According to the result of Bartlett test, it was concluded that explanatory factor analysis could be applied to these 23 articles ( $\mathrm{p}=0.000)$. In explanatory factor analysis "Basic Components Analysis" method was applied and "Varimax" rotating was used.

Table 1 - Explanatory Factor Analysis and Reliabilities

\begin{tabular}{l|l}
\hline & \\
\hline Negative Impact & 0,867 \\
\hline 1.Taxes collected from public will increase & 0,847 \\
2.Health expenditures will increase & 0,839 \\
3.City hospitals project will put public under debt load & 0,782 \\
4.Closure of many education - research hospitals will negatively affect health staff \\
$\begin{array}{l}\text { 5.Since individuals will experience problems in accessing to city hospitals, private } \\
\text { hospitals in the vicinity will be preferred more }\end{array}$ \\
$\begin{array}{l}\text { 6.Keeping the authority of some medical processes limited to the city hospitals } \\
\text { will create and environment in violation of fairness and efficiency }\end{array}$ \\
$\begin{array}{l}\text { 7.High number of bed capacity will crease problems for the hospital management. } \\
\text { Number of individuals purchasing private health insurance will increase. }\end{array}$ \\
$\begin{array}{l}\text { Problem of transportation to city hospitals will increase the demand towards } \\
\text { emergency health services in private hospitals in city centers }\end{array}$ \\
$\begin{array}{l}\text { City hospitals will seek for foreign patients in order to increase capacity use. } \\
\text { Distance of city hospitals to city center will create problems for patients to access } \\
\text { service }\end{array}$ & 0,774 \\
\hline
\end{tabular}




\begin{tabular}{|c|c|c|c|}
\hline Positive Impact & & $\% 21,662$ & 0,922 \\
\hline Number of existing beds will increase as the city hospitals start service & 0,866 & & \\
\hline Service range will increase & 0,860 & & \\
\hline $\begin{array}{l}\text { Number of polyclinics and patients examined will increase as the city hospitals } \\
\text { start service }\end{array}$ & 0,854 & & \\
\hline Quality of health services will increase when city hospitals start service & 0,818 & & \\
\hline $\begin{array}{l}\text { Number of beds in the rooms will be deceased with wide and spacious hospital } \\
\text { structures and risk of infectious diseases will decrease }\end{array}$ & 0,809 & & \\
\hline City hospitals will be administered by a more professional team. & 0,741 & & \\
\hline $\begin{array}{l}\text { It will be possible to access easier to special branch hospitals when required as } \\
\text { enabled by being a campus }\end{array}$ & 0,634 & & \\
\hline Impact on Health Tourism and Competition & & $\% 16,211$ & 0,885 \\
\hline $\begin{array}{l}\text { In case that sufficient capacity is developed in the diagnosis and treatment of rate } \\
\text { diseases, a regional potential will be created for health tourism. }\end{array}$ & 0,868 & & \\
\hline City hospitals will take a role in the field of health tourism. & 0,832 & & \\
\hline $\begin{array}{l}\text { The technological infrastructure of the hospitals will be improved with city } \\
\text { hospitals }\end{array}$ & 0,772 & & \\
\hline City hospitals will increase the competition between private hospitals. & 0,701 & & \\
\hline $\begin{array}{l}\text { Private health sector, which is in competition with city hospitals, will seek ways to } \\
\text { improve the existing quality in order to survive. }\end{array}$ & 0,681 & & \\
\hline \multirow[t]{2}{*}{ Total } & & $\% 66,382$ & 0,882 \\
\hline & $=0,900$ & \multicolumn{2}{|c|}{ Bartlett's p=0,000 } \\
\hline
\end{tabular}

As a result of the explanatory factor analysis, it was seen that 23 articles measuring the opinions on city hospital were separated into 3 factors. $1^{\text {st }}$ factor comprising 11 articles explain $28.509 \%$ of the total structure. Since the articles covering the negative opinions related to city hospital are collected under $1^{\text {st }}$ factor, this factor is called the negative impact factor. $1^{\text {st }}$ factor comprising 7 articles explain $28.509 \%$ of the total structure. Since the articles covering the positive opinions related to city hospital are collected under $2^{\text {nd }}$ factor, this factor is called the positive impact factor. $3^{\text {rd }}$ factor comprising 5 articles explain $16.211 \%$ of the total structure. Since the articles related to the impact of city hospitals on health tourism and competition are collected together in the $3^{\text {rd }}$ factor, this factor was called health tourism and competition impact factor. When the factor loads of articles in these 3 factors are examined, it was seen that the factor loads of all articles were above 0.500 and there was no article loaded above 0.500 to more than 1 factor.

After the explanatory factor analysis, reliability analysis was applied to factors and the total structure and it was seen that the reliabilities were high. Th Cronbach Alpha coefficient of the "Negative Impact" factor comprising 11 articles is 0.930; of "Health Tourism and Impact on Competition" comprising 7 articles is 0.922; of "Impact on Health Tourism and Competition" comprising 5 articles is 0.885 ; and of the whole structure comprising 23 articles is 0.882 . It was seen that no article decreased Cronbach Alpha coefficient. 


\section{Findings}

The findings obtained as a result of research are given under three headings below. First the findings obtained from individuals who have responded the questionnaire were handled within the scope of the research and presented in the form of tables, and afterwards the findings obtained from health professionals were given. As the third and the last one, there is the section where the analysis is done and evaluated from the point of all participants.

\subsection{Findings Related to Individuals Who Are Not Health Professionals.}

$54.1 \%$ of individuals who participated in the research are women and $45.9 \%$ are men. Whereas $35.9 \%$ of the participants are between 20- 29 age group, 45\% are between 30- 39 age group and

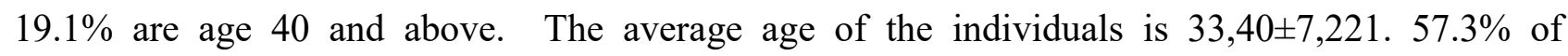
individuals who participated in the research are married and $42.7 \%$ are single. Whereas the educational status of $4.1 \%$ is secondary education, $10.5 \%$ have associate degree, $63.2 \%$ have undergraduate degree, $20 \%$ masters and $2.3 \%$ other.

Whereas $20.9 \%$ of the individuals who participated in the research learned the information on city hospital from the Ministry of Health, 32.3\% learned through Social Media and 46.8\% through Mass Communication Means. $86.8 \%$ of the individuals who participated in the research expressed that they regularly use social media.

Whereas the "Negative Impact" level of individuals who participated in the research is 3,60 0,957 , the "Positive Impact" level is 3,72 $\pm 1,067$ and the "Impact on Health Tourism and Competition" is $3,69 \pm 0,995$.

Table 2. Descriptive Statistics Related to Factors

\begin{tabular}{lllll}
\hline $\mathbf{n}=\mathbf{4 4 0})$ & Average & Standard Deviation & Minimum & Maximum \\
\hline Negative Impact & 3,60 & 0,957 & 1,00 & 5,00 \\
Positive Impact & 3,72 & 1,067 & 1,00 & 5,00 \\
$\begin{array}{l}\text { Impact on Health Tourism and } \\
\text { Competition }\end{array}$ & 3,69 & 0,995 & 1,00 & 5,00 \\
\hline
\end{tabular}

As a result of the Single Direction Analysis of Variance (ANOVA) applied, there is statistically significant differences in terms of levels of "Impact on Health Tourism and Competition" according to the information sources of city hospitals. According to this, levels of "Impact on Health Tourism and Competition" of individuals whose source of information related to city hospitals is the Ministry of Health are significantly higher than citizens whose information source is social media. 
Table 3. Examination of Factor Differences By City Hospitals Information Resources

\begin{tabular}{|c|c|c|c|c|c|c|c|}
\hline \multicolumn{2}{|c|}{ Source of Information } & \multirow{2}{*}{$\begin{array}{l}\text { Number } \\
92\end{array}$} & \multirow{2}{*}{$\begin{array}{l}\text { Average } \\
3,62\end{array}$} & \multirow{2}{*}{$\begin{array}{l}\begin{array}{l}\text { Standard } \\
\text { Deviation }\end{array} \\
1,063\end{array}$} & \multirow[t]{2}{*}{$\mathbf{F}$} & \multirow[t]{2}{*}{$\mathbf{p}$} & \multirow[t]{2}{*}{$\begin{array}{l}\text { Difference } \\
\text { (Tukey) }\end{array}$} \\
\hline \multirow{3}{*}{$\begin{array}{l}\text { Negative } \\
\text { Impact }\end{array}$} & 1.Ministry of Health & & & & & & \\
\hline & 2.Social Media & 142 & 3,52 & 0,932 & \multirow{2}{*}{0,349} & \multirow{2}{*}{0,706} & \multirow{2}{*}{-} \\
\hline & $\begin{array}{l}\text { 3.Mass Communication } \\
\text { Tools }\end{array}$ & 206 & 3,65 & 0,930 & & & \\
\hline \multirow{3}{*}{$\begin{array}{l}\text { Positive } \\
\text { Impact }\end{array}$} & 1.Ministry of Health & 92 & 3,61 & 1,205 & \multirow{3}{*}{0,835} & \multirow{3}{*}{0,435} & \multirow{3}{*}{-} \\
\hline & 2.Social Media & 142 & 3,65 & 1,091 & & & \\
\hline & $\begin{array}{l}\text { 3.Mass Communication } \\
\text { Tools }\end{array}$ & 206 & 3,82 & 0,983 & & & \\
\hline \multirow{3}{*}{$\begin{array}{l}\text { Impact on } \\
\text { Health } \\
\text { Tourism and } \\
\text { Competition }\end{array}$} & 1.Ministry of Health & 92 & 3,92 & 0,897 & \multirow{3}{*}{3,453} & \multirow{3}{*}{$\mathbf{0 , 0 3 3} *$} & \multirow{3}{*}{$1-2$} \\
\hline & 2.Social Media & 142 & 3,46 & 1,104 & & & \\
\hline & $\begin{array}{l}\text { 3.Mass Communication } \\
\text { Tools }\end{array}$ & 206 & 3,75 & 0,932 & & & \\
\hline
\end{tabular}

* $p<0,05$ (statistically significant)

As a result of the Independent Sample t Test applied, no statistically significant difference was found between women and men citizens, married and single participants, those using social medial regularly and those not using it regularly in terms of "Negative Impact" "Positive Impact" and "Impact on Health Tourism and Competition".

As a result of the Single Direction Analysis of Variance (ANOVA) applied, no statistically significant difference was found in terms of levels of "Negative Impact" "Positive Impact" and "Impact on Health Tourism and Competition" according to the education levels of individuals.

As a result of the Single Direction Analysis of Variance (ANOVA) applied, no statistically significant difference was found in terms of levels of "Negative Impact" "Positive Impact" and "Impact on Health Tourism and Competition" according to age groups of individuals.

\subsection{Analysis Related to Health Professionals}

Whereas $51.6 \%$ of the health professionals who participated in the research were nurses, $21.5 \%$ were physicians, $18.8 \%$ were health technicians, $5.8 \%$ were from other professionals and $2.2 \%$ were administrative staff. Whereas $32.7 \%$ of the participants are in 1-5 service years group, $23.8 \%$ are in 6-10 years, $25.1 \%$ are $11-15$ years, and $18.4 \%$ are 16 years and above. Besides, $90.1 \%$ of the health professionals in question are health professionals, and $9.9 \%$ are administrators; whereas $71.3 \%$ of them work in the Ministry of Health, $16.1 \%$ work in private hospitals and $12.6 \%$ in the university hospitals. When the education levels of the participants are analyzed, the education level of $4.9 \%$ is secondary education, $13.9 \%$ two-year education, $51.6 \%$ undergraduate, $21.5 \%$ masters and $8.1 \%$ 
PhD level, and it was concluded that $89.2 \%$ of the health professionals who participated in the research regularly used social media.

Whereas the "Negative Impact" level of health professionals who participated in the research is

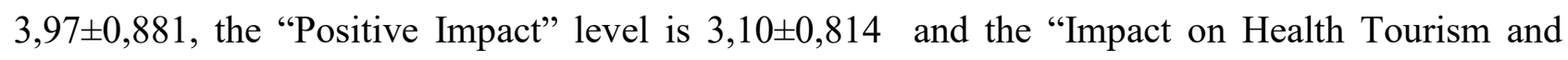
Competition" is $3,78 \pm 0,814$. In addition to thinking that the city hospitals will generally have a negative impact, they also think that there is impact on health tourism and competition. Rate of those who think there will be a positive impact could be said to be lower.

Tablo 4 Descriptive Statistics Related to Factors

\begin{tabular}{|c|c|c|c|c|c|}
\hline$(n=223)$ & & Average & Standard Deviation & Minimum & Maximum \\
\hline Negative Impact & & 3,97 & 0,881 & 1,27 & 5,00 \\
\hline Positive Impact & & 3,10 & 0,957 & 1,00 & 5,00 \\
\hline $\begin{array}{l}\text { Impact on Health } \\
\text { Competition }\end{array}$ & Tourism and & 3,78 & 0,814 & 1,00 & 5,00 \\
\hline
\end{tabular}

As a result of the Single Direction Analysis of Variance (ANOVA), there is statistically significant difference in terms of the "Positive Impact" levels of service provision by professional groups. According to this, the "Positive Impact" levels of service provision of people in other professional groups are significantly higher than the physicians. Physicians agree more that the city hospitals will have negative impact rather than positive impact.

Table 5 - Examination of Factor Differences by Professions

\begin{tabular}{|c|c|c|c|c|c|c|c|}
\hline & & Number & Average & $\begin{array}{l}\text { Standard } \\
\text { Deviation }\end{array}$ & $\mathbf{F}$ & $\mathbf{p}$ & $\begin{array}{l}\text { Difference } \\
\text { (Tukey) }\end{array}$ \\
\hline \multirow{4}{*}{ Negative Impact } & 1.Physician & 96 & 4,11 & 0,725 & \multirow{4}{*}{1,773} & \multirow{4}{*}{0,321} & \multirow{4}{*}{ 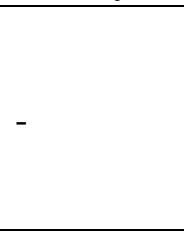 } \\
\hline & 2.Nurse & 230 & 3,92 & 0,950 & & & \\
\hline & 3.Health Technician & 84 & 4,07 & 0,897 & & & \\
\hline & 4. Other & 36 & 3,72 & 0,728 & & & \\
\hline \multirow{4}{*}{ Positive Impact } & 1.Physician & 96 & 2,89 & 0,666 & \multirow{4}{*}{2,858} & \multirow{4}{*}{$\mathbf{0 , 0 3 8 *}$} & \multirow{4}{*}{$1-4$} \\
\hline & 2.Nurse & 230 & 3,06 & 1,128 & & & \\
\hline & 3.Health Technician & 84 & 3,24 & 0,724 & & & \\
\hline & 4. Other & 36 & 3,60 & 0,694 & & & \\
\hline \multirow{4}{*}{$\begin{array}{l}\text { Impact on Health } \\
\text { Tourism and } \\
\text { Competition }\end{array}$} & 1.Physician & 96 & 3,69 & 0,708 & \multirow{4}{*}{0,532} & \multirow{4}{*}{0,661} & \multirow{4}{*}{-} \\
\hline & 2.Nurse & 230 & 3,78 & 0,888 & & & \\
\hline & 3.Health Technician & 84 & 3,90 & 0,760 & & & \\
\hline & 4. Other & 36 & 3,77 & 0,727 & & & \\
\hline
\end{tabular}

* $p<0,05$ (statistically significant)

As a result of the Single Direction Analysis of Variance (ANOVA), there is statistically significant difference in terms of the "Negative Impact" levels of service provision by service year groups. 
According to this, the "Negative Impact" levels of health professionals in the group of 16 years of service and over, are significantly lower compared to people with 1-5 years, 6- 10 years and 11-15 years. In this case, it could be said that health professionals with a service year of more than 16 years approach more positive towards city hospitals.

Table 6 - Examination of Factor Differences by Service Years

\begin{tabular}{|c|c|c|c|c|c|c|c|}
\hline & & Number & Average & $\begin{array}{l}\text { Standard } \\
\text { Deviation }\end{array}$ & $\mathbf{F}$ & $\mathbf{p}$ & $\begin{array}{l}\text { Difference } \\
\text { (Tukey) }\end{array}$ \\
\hline \multirow{4}{*}{ Negative Impact } & 1. 1-5 Years & 146 & 4,03 & 0,741 & \multirow{4}{*}{7,097} & \multirow{4}{*}{$0,000 *$} & \multirow{4}{*}{$4-3,2,1$} \\
\hline & 2. 6-10 Years & 106 & 4,06 & 0,714 & & & \\
\hline & 3. 11-15 Years & 112 & 4,21 & 0,850 & & & \\
\hline & $\begin{array}{l}\text { 4. } 16 \text { years and } \\
\text { above }\end{array}$ & 82 & 3,44 & 1,131 & & & \\
\hline \multirow{4}{*}{ Positive Impact } & 1. 1-5 Years & 146 & 3,25 & 0,738 & \multirow{4}{*}{11,522} & \multirow{4}{*}{$0,000 *$} & \multirow{4}{*}{$\begin{array}{l}2-4 \\
3-1,2,4\end{array}$} \\
\hline & 2. 6-10 Years & 106 & 3,05 & 0,831 & & & \\
\hline & 3. 11-15 Years & 112 & 2,59 & 1,069 & & & \\
\hline & $\begin{array}{l}\text { 4. } 16 \text { years and } \\
\text { above }\end{array}$ & 82 & 3,63 & 0,970 & & & \\
\hline \multirow{4}{*}{$\begin{array}{l}\text { Impact on } \\
\text { Health Tourism } \\
\text { and Competition }\end{array}$} & 1. 1-5 Years & 146 & 3,81 & 0,682 & \multirow{4}{*}{2,579} & \multirow{4}{*}{0,055} & \multirow{4}{*}{-} \\
\hline & 2. 6-10 Years & 106 & 3,80 & 0,772 & & & \\
\hline & 3. 11-15 Years & 112 & 3,95 & 0,836 & & & \\
\hline & $\begin{array}{l}\text { 4. } 16 \text { years and } \\
\text { above }\end{array}$ & 82 & 3,49 & 0,990 & & & \\
\hline
\end{tabular}

* $p<0,05$ (statistically significant)

As a result of the Single Direction Analysis of Variance (ANOVA), there is statistically significant difference in terms of the "Negative Impact" levels of service provision by education level groups. According to this, the "Negative Impact" levels of service provision of health professionals who are in other (Ph.D) education level, are significantly higher than health professionals with secondary education level.

Table 7 - Examination of Factor Differences by Education Levels

\begin{tabular}{|c|c|c|c|c|c|c|c|}
\hline & & Number & Average & $\begin{array}{l}\text { Standard } \\
\text { Deviation }\end{array}$ & $\mathbf{F}$ & $\mathbf{p}$ & $\begin{array}{l}\text { Difference } \\
\text { (Tukey) }\end{array}$ \\
\hline \multirow{5}{*}{ Negative Impact } & 1.Secondary Education & 22 & 3,75 & 1,139 & \multirow{5}{*}{2,623} & \multirow{5}{*}{$0,036 *$} & \multirow{5}{*}{$1-5$} \\
\hline & 2.Associate degree & 62 & 4,27 & 0,600 & & & \\
\hline & 3.Undergraduate degree & 230 & 3,85 & 0,951 & & & \\
\hline & 4.Master's degree & 96 & 3,98 & 0,864 & & & \\
\hline & 5.Ph.D & 36 & 4,38 & 0,368 & & & \\
\hline \multirow{5}{*}{ Positive Impact } & 1.Secondary Education & 22 & 2,78 & 0,997 & \multirow{5}{*}{0,698} & \multirow{5}{*}{0,594} & \multirow{5}{*}{-} \\
\hline & 2.Associate degree & 62 & 3,24 & 0,886 & & & \\
\hline & 3.Bachelor's degree & 230 & 3,10 & 1,067 & & & \\
\hline & 4.Master's degree & 96 & 3,18 & 0,738 & & & \\
\hline & 5.Ph.D & 36 & 2,92 & 0,838 & & & \\
\hline
\end{tabular}




\begin{tabular}{lllllllll}
\hline \multicolumn{2}{c}{} & 1.Secondary Education & 22 & 3,75 & 0,988 & & & \\
Impact on Health & 2.Associate degree & 62 & 3,85 & 0,743 & & & \\
Tourism and & and & 3.Bachelor's degree & 230 & 3,78 & 0,899 & 0,196 & 0,940 & - \\
Competition & 4.Master's degree & 96 & 3,80 & 0,590 & & & \\
& 5.Ph.D & 36 & 3,64 & 0,836 & & & \\
\hline
\end{tabular}

* $p<0,05$ (statistically significant)

\section{Xx Other - Those who are literate and illiterate}

As a result of independent sample t test applied, a statistically significant difference was found in terms of levels of "Impact on Health Tourism and Competition" between the health professionals and administrators and among health professionals who use and do not use social media regularly. According to this, the levels of "Impact on Health Tourism and Competition" of health professionals who regularly use social media, are significantly higher compared to health professionals who do not use social media regularly.

Table 8 Examination of Factor Differences By Status of Regularly Using Social Media

\begin{tabular}{|c|c|c|c|c|c|c|c|}
\hline & & & Number & Average & $\begin{array}{l}\text { Standard } \\
\text { Deviation }\end{array}$ & $\mathbf{t}$ & $\mathbf{p}$ \\
\hline \multirow{2}{*}{\multicolumn{2}{|c|}{ Negative Impact }} & Yes & 398 & 3,99 & 0,896 & \multirow{2}{*}{0,651} & \multirow{2}{*}{0,516} \\
\hline & & No & 48 & 3,86 & 0,756 & & \\
\hline \multirow{2}{*}{ Positive Impact } & & Yes & 398 & 3,09 & 0,980 & \multirow{2}{*}{$-0,630$} & \multirow{2}{*}{0,529} \\
\hline & & No & 48 & 3,22 & 0,745 & & \\
\hline \multirow{2}{*}{$\begin{array}{l}\text { Impact on } \\
\text { Tourism } \\
\text { Competition }\end{array}$} & \multirow{2}{*}{$\begin{array}{r}\text { Health } \\
\text { and }\end{array}$} & Yes & 398 & 3,84 & 0,804 & \multirow[b]{2}{*}{3,257} & \multirow[b]{2}{*}{$\mathbf{0 , 0 0 1 *}$} \\
\hline & & No & 48 & 3,28 & 0,736 & & \\
\hline
\end{tabular}

When we examine the responses given by health professionals in relation to city hospitals, it was seen that the majority have replied as "Agree" and "Totally Agree" to the statements "Work burden of health professionals will increase with city hospitals practice" "Health professionals will more suffer from psychological problems such as exhaustion, insomnia and depression" and "It will make coordination and consultation services harder" There was a majority answering the "No Idea" and "Agree" responses to the statements "Work burden of health professionals will increase with city hospitals practice" and "Resting rooms and resting hours of health professionals will be cancelled". 
Table 9 Distribution of Responses Given to Statements Related to City Hospitals

\begin{tabular}{|c|c|c|c|c|c|c|c|c|c|c|}
\hline & $\begin{array}{l}\text { Tota } \\
\text { Disa } \\
\\
\dot{\bar{D}} \\
\text { है } \\
\text { Z }\end{array}$ & 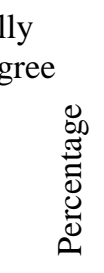 & 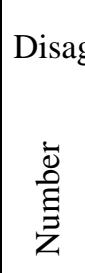 & 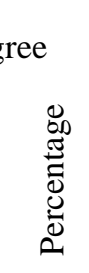 & 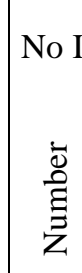 & 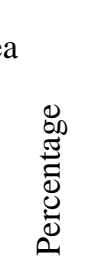 & $\begin{array}{l}\dot{\varpi} \\
\text { है } \\
\text { z }\end{array}$ & 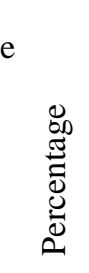 & $\begin{array}{l}\text { Totall } \\
\text { Agree } \\
\\
\overline{\bar{\nu}} \\
\overline{\text { a }} \\
\bar{z}\end{array}$ & 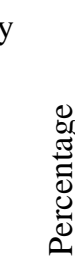 \\
\hline $\begin{array}{l}\text { Work burden of health professionals will } \\
\text { increase with city hospitals practice }\end{array}$ & 26 & 5,8 & 22 & 4,9 & 22 & 4,9 & 188 & 42,2 & 188 & 42,2 \\
\hline $\begin{array}{l}\text { Health professionals will be illegally obliged } \\
\text { to be on duty only one single person }\end{array}$ & 28 & 6,3 & 46 & 10,3 & 138 & 30,9 & 114 & 25,6 & 120 & 26,9 \\
\hline $\begin{array}{l}\text { Health professionals will more suffer from } \\
\text { psychological problems such as exhaustion, } \\
\text { insomnia and depression }\end{array}$ & 24 & 5,4 & 56 & 12,6 & 36 & 8,1 & 186 & 41,7 & 144 & 32,3 \\
\hline $\begin{array}{l}\text { Resting rooms and resting hours of health } \\
\text { professionals will be cancelled }\end{array}$ & 24 & 5,4 & 94 & 21,1 & 118 & 26,5 & 122 & 27,4 & 88 & 19,7 \\
\hline $\begin{array}{l}\text { This will negatively affect the income of } \\
\text { health professionals }\end{array}$ & 24 & 5,4 & 74 & 16,6 & 98 & 22,0 & 134 & 30,0 & 116 & 26,0 \\
\hline $\begin{array}{l}\text { It will make coordination and consultation } \\
\text { services harder }\end{array}$ & 28 & 6,3 & 32 & 7,2 & 38 & 8,5 & 140 & 31,4 & 208 & 46,6 \\
\hline
\end{tabular}

\section{Analysis for All Participants}

As a result of the Single Direction Analysis of Variance (ANOVA) applied, statistically significant difference was found in terms of levels of "Negative Impact" "Positive Impact" and "Impact on Health Tourism and Competition" according city hospitals information resources. According to this, "Negative Impact" levels of individuals whose source of information related to city hospitals is the Ministry of Health, are significantly higher than citizens whose information source is social media and mass communication means. "Positive Impact" levels of individuals whose source of information related to city hospitals is the Ministry of Health, are significantly higher than citizens whose information source is social media and mass communication means. "Impact of Health Tourism and Competition" levels of individuals whose source of information related to city hospitals is the social media, are significantly higher than citizens whose information source is the Ministry of Health and mass communication means.

Table 10 Examination of Factor Differences By City Hospitals Information Resources

\begin{tabular}{|c|c|c|c|c|c|c|c|}
\hline & & Number & Average & $\begin{array}{l}\text { Standard } \\
\text { Deviation } \\
\end{array}$ & $\mathbf{F}$ & $\mathbf{p}$ & $\begin{array}{l}\text { Difference } \\
\text { (Tukey) }\end{array}$ \\
\hline \multirow{3}{*}{$\begin{array}{l}\text { Negative } \\
\text { Impact }\end{array}$} & 1.Ministry of Health & 336 & 4,04 & 0,886 & \multirow{3}{*}{11,598} & \multirow{3}{*}{$0,000^{*}$} & \multirow{3}{*}{$1-2,3$} \\
\hline & 2.Social Media & 210 & 3,52 & 0,865 & & & \\
\hline & $\begin{array}{l}\text { 3.Mass Communication } \\
\text { Tools }\end{array}$ & 340 & 3,70 & 0,972 & & & \\
\hline \multirow{2}{*}{$\begin{array}{l}\text { Positive } \\
\text { Impact }\end{array}$} & 1.Ministry of Health & 336 & 3,11 & 1,087 & \multirow{2}{*}{11,165} & \multirow{2}{*}{$0,000 *$} & \multirow{2}{*}{$1-2,3$} \\
\hline & 2.Social Media & 210 & 3,61 & 0,985 & & & \\
\hline
\end{tabular}




\begin{tabular}{lllllllll}
\hline & $\begin{array}{l}\text { 3.Mass Communication } \\
\text { Tools }\end{array}$ & 340 & 3,58 & 1,010 & & & \\
\hline Impact & on & 1.Ministry of Health & 336 & 3,93 & 0,780 & & & \\
$\begin{array}{l}\text { Health } \\
\text { Tourism }\end{array}$ & $\begin{array}{l}\text { 2.Social Media } \\
\text { and }\end{array}$ & 210 & 3,44 & 1,005 & & & \\
Competition & 3.Mass Communication & 340 & 3,74 & 0,920 & & & & \\
\hline
\end{tabular}

* $p<0,05$ (statistically significant)

As a result of Independent Sample t Test conducted, there is no statistical difference in terms of "Negative Impact" "Positive Impact" and "Impact on Health Tourism and Competition" between women and men.

As a result of the Single Direction Analysis of Variance (ANOVA), there is statistically significant difference in terms of the "Positive Impact" levels by age groups. According to this, the "Positive Impact" levels of persons in the age group 20- 29 are significantly more than the persons in $30-39$ age group.

Table 11 - Examination of Factor Differences by Age

\begin{tabular}{|c|c|c|c|c|c|c|c|}
\hline & & Number & Average & $\begin{array}{l}\text { Standard } \\
\text { Deviation } \\
\end{array}$ & $\mathbf{F}$ & $\mathbf{p}$ & $\begin{array}{l}\text { Difference } \\
\text { (Tukey) }\end{array}$ \\
\hline \multirow{3}{*}{ Negative Impact } & Age $20-29$ & 306 & 3,78 & 0,900 & \multirow{3}{*}{1,972} & \multirow{3}{*}{0,140} & \multirow{3}{*}{-} \\
\hline & 2.Age 30-39 & 390 & 3,87 & 0,887 & & & \\
\hline & 3.Age 40 and above & 190 & 3,64 & 1,076 & & & \\
\hline \multirow{3}{*}{ Positive Impact } & Age $20-29$ & 306 & 3,59 & 0,972 & \multirow{3}{*}{4,499} & \multirow{3}{*}{$0,012 *$} & \multirow{3}{*}{$1-2$} \\
\hline & 2.Age 30-39 & 390 & 3,25 & 1,057 & & & \\
\hline & 3.Age 40 and above & 190 & 3,45 & 1,149 & & & \\
\hline \multirow{3}{*}{$\begin{array}{l}\text { Impact on Health } \\
\text { Tourism and } \\
\text { Competition }\end{array}$} & Age $20-29$ & 306 & 3,73 & 0,846 & \multirow{3}{*}{1,216} & \multirow{3}{*}{0,298} & \multirow{3}{*}{-} \\
\hline & 2.Age 30-39 & 390 & 3,68 & 0,912 & & & \\
\hline & 3.Age 40 and above & 190 & 3,86 & 0,994 & & & \\
\hline
\end{tabular}

* $p<0,05$ (statistically significant)

As a result of Independent Sample t Test conducted, there is a statistically significant difference in terms of "Positive Impact" and "Impact on Health Tourism and Competition" between married and single individuals. According to this, the "Positive Impact" and "Impact on Health Tourism and Competition" levels are significantly more than the married people. 
Table 12 - Examination of Factor Differences by Civil Status

\begin{tabular}{|c|c|c|c|c|c|c|}
\hline & & Number & Average & $\begin{array}{l}\text { Standard } \\
\text { Deviation }\end{array}$ & $\mathbf{t}$ & $\mathbf{p}$ \\
\hline \multirow{2}{*}{ Negative Impact } & Married & 526 & 3,76 & 0,923 & \multirow{2}{*}{$-0,734$} & \multirow{2}{*}{0,463} \\
\hline & Single & 360 & 3,83 & 0,959 & & \\
\hline \multirow{2}{*}{ Positive Impact } & Married & 526 & 3,30 & 1,100 & \multirow{2}{*}{$-2,658$} & \multirow{2}{*}{$0,008 *$} \\
\hline & Single & 360 & 3,57 & 0,974 & & \\
\hline \multirow{2}{*}{$\begin{array}{l}\text { Impact on Health Tourism } \\
\text { and Competition }\end{array}$} & Married & 526 & 3,66 & 0,907 & \multirow{2}{*}{$-2,148$} & \multirow{2}{*}{$\mathbf{0 , 0 3 2} *$} \\
\hline & Single & 360 & 3,85 & 0,901 & & \\
\hline
\end{tabular}

* $p<0,05$ (statistically significant)

As a result of Independent Sample t Test conducted, there is a statistically significant difference in terms of "Negative Impact" and "Positive Impact" between individuals and health professionals. According to this, whereas the "Negative Impact" levels of service provision of health professionals are significantly more compared to individuals, the "Positive Impact" levels of service provision is significantly low.

Table 13 - Examination of Factor Differences by Civil Status

\begin{tabular}{|c|c|c|c|c|c|c|}
\hline & & Number & Average & $\begin{array}{l}\text { Standard } \\
\text { Deviation }\end{array}$ & $\mathbf{t}$ & $\mathbf{p}$ \\
\hline \multirow[b]{2}{*}{ Negative Impact } & Individual & 440 & 3,60 & 0,957 & \multirow[b]{2}{*}{$-4,265$} & \multirow[b]{2}{*}{ 0,000: } \\
\hline & $\begin{array}{l}\text { Health } \\
\text { Professional }\end{array}$ & 446 & 3,97 & 0,881 & & \\
\hline \multirow[b]{2}{*}{ Positive Impact } & Individual & 440 & 3,72 & 1,067 & \multirow[b]{2}{*}{6,403} & \multirow[b]{2}{*}{$0,000 *$} \\
\hline & $\begin{array}{l}\text { Health } \\
\text { Professional }\end{array}$ & 446 & 3,10 & 0,957 & & \\
\hline \multirow{2}{*}{$\begin{array}{l}\text { Impact on } \\
\text { Tourism } \\
\text { Competition }\end{array}$} & Individual & 440 & 3,69 & 0,995 & \multirow[b]{2}{*}{$-1,087$} & \multirow[b]{2}{*}{0,278} \\
\hline & $\begin{array}{l}\text { Health } \\
\text { Professional }\end{array}$ & 446 & 3,78 & 0,814 & & \\
\hline
\end{tabular}

$* p<0,05$ (statistically significant)

As a result of the Single Direction Analysis of Variance (ANOVA) applied, no statistically significant difference was found in terms of levels of "Negative Impact" "Positive Impact" and "Impact on Health Tourism and Competition" according to the educational levels of individuals according to the education levels of citizens and health professionals.

As a result of the independent sampling t test applied, a statistically significant difference is present in terms of responses given to the following expressions between individuals and health professionals:

"Quality of health services will increase when city hospitals start service" "Number of existing beds will increase as the city hospitals start service" 
"Number of polyclinics and patients examined will increase as the city hospitals start service"

"Distance of city hospitals to city center will create problems for patients to access service"

"Number of beds in the rooms will be deceased with wide and spacious hospital structures and risk of infectious diseases will decrease"

"Service range will increase"

"High number of bed capacity will crease problems for the hospital management"

"City hospitals will be administered by a more professional team"

"City hospitals project will put public under debt load"

"Taxes collected from public will increase"

"Health expenditures will increase"

"Number of individuals purchasing private health insurance will increase"

"Since individuals will experience problems in accessing to city hospitals, private hospitals in the vicinity will be preferred more"

"City hospitals will increase the competition between private hospitals"

"Private health sector, which is in competition with city hospitals, will seek ways to improve the existing quality in order to survive"

"City hospitals will seek for foreign patients in order to increase capacity use" .

According to this, whereas the levels of agreement of citizens with he following statements are significantly higher compared to health professionals;

"Quality of health services will increase when city hospitals start service"

"Number of existing beds will increase as the city hospitals start service"

"Number of polyclinics and patients examined will increase as the city hospitals start service"

"Number of beds in the rooms will be deceased with wide and spacious hospital structures and risk of infectious diseases will decrease"

"Service range will increase"

"City hospitals will be administered by a more professional team"

"Private health sector, which is in competition with city hospitals, will seek ways to improve the existing quality in order to survive"

the levels of agreement with the following expressions are significantly lower compared to health professionals:

"Distance of city hospitals to city center will create problems for patients to access service"

"High number of bed capacity will crease problems for the hospital management"

"City hospitals project will put public under debt load"

"Taxes collected from public will increase" 


\section{"Health expenditures will increase"}

"Number of individuals purchasing private health insurance will increase"

"Since individuals will experience problems in accessing to city hospitals, private hospitals in the vicinity will be preferred more"

"City hospitals will increase the competition between private hospitals"

"City hospitals will seek for foreign patients in order to increase capacity use"

Table 14 Analysis of Differences By Responses Given by Citizens and Health Professionals to Statements Related to City Hospitals

\begin{tabular}{|c|c|c|c|c|c|c|}
\hline & \multicolumn{2}{|l|}{ Citizen } & \multicolumn{2}{|c|}{$\begin{array}{l}\text { Health } \\
\text { Professional }\end{array}$} & \multirow[b]{2}{*}{$\mathbf{t}$} & \multirow[b]{2}{*}{$\mathbf{p}$} \\
\hline & Average & S.S & Average & S.S & & \\
\hline Quality of health services will increase when city hospitals start service & 3,60 & 1,28 & 2,65 & 1,31 & 7,711 & 0,000* \\
\hline Number of existing beds will increase as the city hospitals start service & 3,90 & 1,19 & 3,16 & 1,29 & 6,304 & $0,000 *$ \\
\hline $\begin{array}{l}\text { Number of polyclinics and patients examined will increase as the city } \\
\text { hospitals start service }\end{array}$ & 3,79 & 1,23 & 3,00 & 1,27 & 6,611 & $0,000 *$ \\
\hline $\begin{array}{l}\text {-Distance of city hospitals to city center will create problems for patients } \\
\text { to access service }\end{array}$ & 3,90 & 1,24 & 4,30 & 1,02 & $-3,705$ & $0,000 *$ \\
\hline $\begin{array}{l}\text { It will be possible to access easier to special branch hospitals when } \\
\text { required as enabled by being a campus }\end{array}$ & 3,75 & 1,16 & 3,67 & 0,99 & 0,753 & 0,452 \\
\hline $\begin{array}{l}\text { Number of beds in the rooms will be deceased with wide and spacious } \\
\text { hospital structures and risk of infectious diseases will decrease }\end{array}$ & 3,95 & 1,13 & 3,45 & 1,28 & 4,291 & $\mathbf{0 , 0 0 0 *}$ \\
\hline Service range will increase & 3,78 & 1,25 & 3,22 & 1,24 & 4,711 & $0,000 *$ \\
\hline $\begin{array}{l}\text { High number of bed capacity will crease problems for the hospital } \\
\text { management. }\end{array}$ & 3,29 & 1,38 & 3,95 & 1,26 & $-5,296$ & $0,000 *$ \\
\hline City hospitals will be administered by a more professional team. & 3,27 & 1,33 & 2,56 & 1,33 & 5,614 & $0,000 *$ \\
\hline $\begin{array}{l}\text { Closure of many education - research hospitals will negatively affect } \\
\text { health staff }\end{array}$ & 3,57 & 1,27 & 3,69 & 1,28 & $-1,010$ & 0,313 \\
\hline City hospitals project will put public under debt load & 3,60 & 1,31 & 4,11 & 1,21 & $-4,206$ & $0,000 *$ \\
\hline Taxes collected from public will increase & 3,71 & 1,29 & 4,13 & 1,23 & $-3,479$ & $0,001 *$ \\
\hline Health expenditures will increase. & 3,78 & 1,24 & 4,09 & 1,19 & $-2,666$ & $0,008 *$ \\
\hline Number of individuals purchasing private health insurance will increase. & 3,42 & 1,23 & 3,88 & 1,22 & $-4,007$ & $0,000 *$ \\
\hline $\begin{array}{l}\text { Since individuals will experience problems in accessing to city hospitals, } \\
\text { private hospitals in the vicinity will be preferred more }\end{array}$ & 3,54 & 1,21 & 4,12 & 1,05 & $-5,345$ & $0,000 *$ \\
\hline $\begin{array}{l}\text { Keeping the authority of some medical processes limited to the city } \\
\text { hospitals will create and environment in violation of fairness and } \\
\text { efficiency }\end{array}$ & 3,73 & 1,20 & 3,79 & 1,13 & $-0,560$ & 0,576 \\
\hline City hospitals will increase the competition between private hospitals. & 3,73 & 1,18 & 3,94 & 1,01 & $-2,006$ & $\mathbf{0 , 0 4 5 *}$ \\
\hline $\begin{array}{l}\text { Private health sector, which is in competition with city hospitals, will } \\
\text { seek ways to improve the existing quality in order to survive. }\end{array}$ & 3,79 & 1,13 & 3,58 & 1,08 & 1,975 & $0,049 *$ \\
\hline $\begin{array}{l}\text { Problem of transportation to city hospitals will increase the demand } \\
\text { towards emergency health services in private hospitals in city centers }\end{array}$ & 3,81 & 1,11 & 4,00 & 1,02 & $-1,881$ & 0,061 \\
\hline $\begin{array}{l}\text { City hospitals will seek for foreign patients in order to increase capacity } \\
\text { use. }\end{array}$ & 3,28 & 1,24 & 3,67 & 1,13 & $-3,480$ & $0,001 *$ \\
\hline City hospitals will take a role in the field of health tourism. & 3,57 & 1,15 & 3,73 & 0,95 & $-1,623$ & 0,105 \\
\hline $\begin{array}{l}\text { In case that sufficient capacity is developed in the diagnosis and } \\
\text { treatment of rate diseases, a regional potential will be created for health } \\
\text { tourism. }\end{array}$ & 3,62 & 1,19 & 3,81 & 1,04 & $-1,828$ & 0,068 \\
\hline $\begin{array}{l}\text { The technological infrastructure of the hospitals will be improved with } \\
\text { city hospitals }\end{array}$ & 3,75 & 1,19 & 3,86 & 1,01 & $-1,060$ & 0,290 \\
\hline
\end{tabular}

\section{* $p<0,05$ (statistically significant)}

\section{Conclusion and Recommendations}


With the health transformation program, the Ministry of Health has undergone a structure and functional transformation. The structural part of the transformation has taken place over the integrated health campuses which are the field of implementation of Public Private Partnership Model, and the functional part has been carried out over the transformation of planning, regulation and inspection roles of the Ministry of Health. Public Private Partnership Model is the model wherein the public sector is placed next to the private sector and performs its targets by financing the service areas through private sector. In this case, the private sector makes a safe investment by being on the side of the state. The state, which benefits from the private sector as regards to construction of city hospitals and provision of services in the campus, acts on the grounds of saving and efficiency. However, the private sector thinks the process after investment and focuses on the expense value, namely how much return will the money allocated to investment will bring. Although the construction of city hospitals has economic justifications, it could be seen that the concern of health professionals is higher on the issue that problems could be experienced in access of citizens to health services.

This study, which is conducted in order to analyze the opinions, knowledge levels and differences of opinion of citizens and health professionals on city hospitals, which have not yet started operations in Ankara Province, supports this hypothesis assumed.

An important finding obtained in the research demonstrates that there is a statistically significant difference in terms of "Negative Impact" and "Positive Impact" levels of city hospitals among individuals and health professionals. According to this, whereas the "Negative Impact" levels of service provision of health professionals are significantly more compared to individuals, the "Positive Impact" levels of service provision is significantly low. The meaning of this is that whereas the health professionals have negative opinions in relation to city hospitals practice, the citizens have more positive opinions. For that reason, it could be said that health professionals have more information about the issue. Among the health professionals, it was determined that the opinion of the physicians in particular on the negative impact of city hospitals is significantly more than other health professionals. For example, it could be said that physicians support more the premise sthat we have considered under negative impacts such as the integrated health campuses creating transportation problem, increase of the tax received from public, increase of health expenditures, and the debt burden caused by this project and the city hospital project.

Another finding is that, the "Negative Impact" levels of health professionals in the group of 16 years of service in their profession and over, are significantly lower compared to people with 1-5 years, 6- 10 years and 11-15 years. Namely, health professionals who have an experience of 16 
years and more in their profession have preferred less compared to others the statements in the negative impact group under city hospitals practices.

One of the most important findings is that as the level of education increases, the negative concern levels of health professionals on city hospitals also increase.

It is seen that health professionals and individuals think that city hospitals will have positive Impact on Health Tourism and Competition. However, as a result of independent sample t test applied, a statistically significant difference was found in terms of levels of "Impact on Health Tourism and Competition" of city hospital practice between the health professionals who use and do not use social media regularly. According to this, the levels of "Impact on Health Tourism and Competition" of health professionals who regularly use social media, are significantly higher compared to health professionals who do not use social media regularly. This could enable us to make the comment that social media is effective in terms of informing the health professionals.

It is necessary to handle both positive and negative aspects of city hospitals projects. Due to the fact that some city hospitals which have launched operations are remote from the city, there is a concern that it will not be possible to benefit from health services in emergencies and as a result of this, people will be required to apply to private hospitals in their vicinity. Besides, health professionals consider that the increasing number of beds will create problems in hospital administration, that the project will cause a significant debt on the public and when the targeted number of patients is not reached, the taxes received from people will also increase. Based on this, taking into account the problems that could occur in access to city hospitals in the following projects and those that could occur in transportation between units in the campus, relevant cautions shall be taken in order to carry out the project with a professional understanding of team and management .

Another positive aspect of city hospitals is that the patient satisfaction will increase as the buildings will be modern and comfortable. Another positive aspect is that improvement will be ensured in technologic infrastructure in hospitals with the city hospitals.

It is necessary to evaluate Public Private Partnership projects very well as in the case of other public investments and more diligence shall be demonstrate to the stage of planning before starting the implementation. It is beneficial that the study shall be conducted after the city hospitals in Ankara start operations and compare the opinions before and after the operation, and perform it also in other provinces. 


\section{References}

Altan, Y., Kerman, U., Aktel, M., Metin, Y., Eke, E. (2013), "Yerel Yönetimlerde Kamu Özel Ortaklığ1 Uygulaması Büyükkabaca Belediyesi Örneği”, Uluslararası Alanya İşletme Fakültesi Dergisi, 5 (3), 9-17.

Barlow J., Roehrich J., Wright S. (2013). Europe Sees Mixed Results From Public-Private Partnerships For Building And Managing Health Care Facilities And Services", HEALTH AFFAIRS 32, NO. 1, 146-154. doi 10.1377/hlthaff.2011.1223

Bülbül, D. (2017), “Türkiye’de Kamu Özel İşbirliği Uygulamasının Mali Saydamlık Açısından Değerlendirilmesi”, Uluslararası Bilimsel Araştırmalar Dergisi, 2 (7).

Çınar, N. F., Türkoğlu, Ç., Tütünsatar, A. (2017), "Kamu-Özel Ortaklığı/İşbirliğgi Modeli Ve Sağlık Hizmetlerinin Sunumunda Hizmet Memnuniyetinin Ölçülmesi Entegre Sağlık Kampüsleri (Şehir Hastaneleri) İçin Bir Araştırma”, Süleyman Demirel Üniversitesi Sosyal Bilimler Enstitüsü Dergisi, 4 (29), 215-232.

Karasu, K. (2011), "Sağlık Hizmetlerinin Örgütlenmesinde Kamu-Özel Ortaklı̆̆ı”, Ankara Üniversitesi SBF Dergisi, 66 (3), 217-262.

Kerman, U., Altan, Y., Aktel, M., Eke E. (2012), “Sağlık Hizmetlerinde Kamu Özel Ortaklığı Uygulaması”, Süleyman Demirel Üniversitesi İktisadi ve İdari Bilimler Fakültesi Dergisi, 17 (3), 1-23.

McKee M., Edwards N., Atun R. (2006) "Public-private partnerships for hospitals", Bulletin of the World Health Organization, 84 (11), 890- 896.

Raman A.V., Björkman J.W. (2015) Public-Private Partnerships in Healthcare. In Kuhlmann E., Blank R.H., Bourgeault I.L., Wendt C. (eds) The Palgrave International Handbook of Healthcare Policy and Governance. Palgrave Macmillan, London.

Sonğur, C., Top, M. (2018), “Türkiye'de Sağlık Sektöründe Kamu-Özel İşbirliği Modeli Paydaş Görüşlerine Dayalı Bir Alan Araştırması”, Sosyal Güvenlik Dergisi, 8 (1), 159-186.

Gürbüz, S. Ve Şahin, F. (2014). Sosyal Bilimlerde Araştırma Yöntemleri. Ankara. Seçkin Yayınları.

Şenel Tekin, P. (2017), "Küresel Kamu Özel Ortaklığı Uygulamaları ve Türkiye Sağlık Sektörü, Açısından Bir Değerlendirme", Ankara Sağlık Hizmetleri Dergisi, 16 (2), 5-20.

Thadani K. B. (2014). "Public Private Partnership in the Health Sector Boon or Bane", Procedia - Social and Behavioral Sciences 157, 307- 316. doi 10.1016/j.sbspro.2014.11.033

Yerlikaya, G. K. (2013), “Türkiye'de Yap-İşlet-Devret Modeli Çerçevesinde Görevli Şirkete Tanınan Yatırım Dönemi ve Proje Kapsamında Katma Değer Vergisi İstisnası”, İ̈HFM, LXXI (2), 527-542.

http //www.anayasa.gov.tr/icsayfalar/mevzuat/1982anayasas \%C4\%B1.html

http://www.mevzuat.gov.tr/Mevzuat Metin/1.5.3996.pdf

https://ppp.worldbank.org/public-private-partnership/ppp-health

http://www.resmigazete.gov.tr/eskiler/2006/07/20060722-2.htm

http://tusside.tubitak.gov.tr/sites/images/sehir_hastaneleri_yonetim_ve_isletim_modeli_whitepaper.pdf 